\title{
Can the Fair Trade Movement Enrich Traditional Business Ethics? An Historical Study of Its Founders in Mexico
}

\author{
Luc K. Audebrand \\ Thierry C. Pauchant
}

\begin{abstract}
As the need for more diversity in business ethics is becoming more pressing in our global world, we provide an historical study of a Fair Trade (FT) movement, born in rural Mexico. We first focus on the basic assumptions of its founders, which include a workerpriest, Frans van der Hoff, a group of native Indians and local farmers who formed a cooperative, and an NGO, Max Havelaar. We then review both the originalities and challenges of the FT movement and its potential contributions to the current theories and practices in business ethics.
\end{abstract}

KEY WORDS: business ethics, community movement and social justice, traditional and native religions, Fair Trade

Everyone who works has the right to just and favourable remuneration ensuring for himself and his family an existence worthy of human dignity (Universal Declaration of Human Rights, article 23, paragraph 3)

While the field of business ethics has progressed much in the last 20 years, it is still largely viewed as Western-centric and focusing on too few frameworks, such as those introduced by Emmanuel Kant or John Stuart Mill (Frederick, 2000; McDonald and Pak, 1996; O'Fallon and Butterfield, 2005; Schwartz, 2005). Several authors have called for more diversity both in the ethical theories and in the practices advocated in order to better address the complexity of our global world (Ciulla et al., 2007; Goodpaster et al., 2006; Pauchant et al., 2002; Samuelson, 2006; Shanahan and Wang, 2003; Taylor, 1989). It is in this spirit that we present in this article the emergence of the Fair Trade (FT) movement in rural Mexico and the birth of the Max Havelaar label, which today involves several hundred millions of producers and consumers. While a few scientific articles have focussed on some ethical issues related to this movement (Davies and Crane, 2003; Hira and Ferrie, 2006; Melo and Wolf, 2005; Moore, 2004), none has really delved into its historical and philosophical roots. This exploration is in particular relevant for an Anglo-saxon audience, as most of the publications available on this subject are in French, Spanish or Dutch. Further, this lack of in-depth information on the cultural and ethical "basic assumptions" (Schein, 1985) or on the "hyper-goods" (Taylor, 1989) which have inspired the founders of the FT movement can, however, hinder its potential contributions to the current theory and practice of business ethics.

The philosophy and practice of FT has emerged out of a very particular context. At a time of growing opposition towards the two dominant logics of market-driven or government-controlled markets, the FT movement has taken root in small communities at the margins of these two systems. In fact, FT was designed to ensure the survival of the community and safeguard its dignity. In addition, FT is not rooted in Western countries but rather in so-called "developing countries" or the "South". Furthermore, whereas in the modern Western world, the future of the economy is believed to lie not in the industrial sector or even the services sector but, mostly, in the information sector, FT is rooted in the oldest economic sector, agriculture, a sector in which no more than $2 \%$ to $3 \%$ of the Western workforce participates (OECD, 2005, pp. 16-17). Nonetheless, FT is not anti-modernist, romantic or backward-looking. Today, 2.06 billion men and women still earn their living or subsist by working the land (ILO, 2004, p. 53). 
Although the volume of international trade is currently 14 times greater than what it was after World War II, one third of the planet, or more than two billion people, still live below the poverty line. About 1.4 billion people earn less than US $\$ 2$ per day. Third World countries often depend on exports of raw materials and crops, such as coffee, sugar, cacao or bananas, which have been declining in price for many years (Hira and Ferrie, 2006, p. 112). FT, which constitutes one solution to this problem, is defined as a "commercial network of productiondistribution-consumption oriented towards interdependent, sustainable development" (Fretell and Roca, 2005, p. 99). Its goal is to increase equity in international trade, given that today no market can thrive in isolation. Indeed, FT does not advocate increasing charity or financial aid to developing countries; rather, it proposes an alternative organization of international commercial trade. FT allows small producers in the South to access Northern markets, which helps them to evolve from a position of vulnerability and dependence to one of greater economic self-sufficiency, while improving their social and ecological conditions. Internationally, FT products, distributed in over 20 countries in the North, are helping more than one million rural families in 30 exporting countries in the South (Latin America, Africa, Asia, etc.) to earn their living.

The Dutch worker-priest Frans van der Hoff has played a pivotal role in the development of this movement: he introduced the first certified FT product; co-founded the first international FT label, Max Havelaar, and settled in Latin America in 1970. Since 1980, he has been sharing the life of plantation farmers in a small village in Mexico, the fertile birthplace of modern FT. Van der Hoff was named CEO of the Year in Mexico in 2004. He has also earned an honorary doctorate from the Catholic University of Louvain, Belgium; and was decorated as a Knight of the Legion of Honour by the French government.

\section{Frans van der Hoff and the emergence of the Fair Trade movement in rural Mexico}

Born in 1939 in the Netherlands into a family of 15 children, Frans "Fransisco" van der Hoff was raised on a farm in very humble conditions. He claims he grew up "literally under the cows" (Roozen and van der Hoff, 2001, p. 16). His first memories are of World War II: he was struck by the sight of a charred corpse of a German pilot whose plane had crashed near his farm. Drawn to the priesthood, he recalls the austere quasi-military life at the seminary, but admits that it was there that he learned discipline, introspection and meditation. He also noted the rift between city dwellers and the rural population; he himself had been mocked as a "yokel". Ordained as a priest in 1968, he describes this period as effervescent: Vatican II, the student occupations of universities, large gatherings of the revolutionary left, May '68 in Paris, Martin Luther King jr., the opposition to the Vietnam War, etc. Yet he concludes today that "we believed that the simple defence of human rights, justice and democracy would prevail over abuse" (van der Hoff, 2005, p. 55). After studying history, philosophy and theology in the Netherlands and in Germany (Universities of Nijmegen, Heidelberg, Münster and Berlin) and studying economics under Nobel Prize winner Jan Tinbergen, he earned two doctorate degrees in 1970, in political economics and theology.

During his sojourn as a chair holder at the University of Ottawa from 1970 to 1973, he divided his time between Canada and Chile. In Ottawa, while volunteering at a shelter for drug abusers, he realized that some drug addicts come from well-to-do families "as if a whole generation was lost" (Roozen and van der Hoff, 2001, p. 28). In Santiago he worked in the slums, where he noticed the violence between opposing groups and the need to reduce social schisms. It was there that he met Paulo Freire, who taught him the virtues of dialogue and how awareness and education could be liberating for oppressed populations (Friere, 2000). After the "coup d'etat" in 1973 led by totalitarian leader Pinochet, he took refuge in Mexico, working in Mexico City until 1980. Although a priest and associated with the Catholic Church, he often publicly expressed disappointment, notably at the Church's support for General Pinochet or the visits to the slums by bishops in luxury cars. To ensure his financial independence and to fulfil his quest to share the lot of the most disadvantaged workers, he became a worker-priest, labouring as a travelling shoe salesman, jam maker, axle producer at Ford and farmer. After receiving death threats from the secret police 
in Mexico City, he moved to Ixtepec in the southern state of Oaxaca, where $80 \%$ of the population is native. To this day, he lives among the Zapotec, Miztec, Mixe, Chontales and other tribes.

The birth of the Union of Indian Villages in the Isthmus Region (UCIRI), where the first Max Havelaar product was produced, is itself grounded in the historical context of Mexico (Almanza-Alcade, 2002; Mace, 1998; Norget, 1997; Otero, 1999; van der Hoff, 2005). To promote access to freedom and land ownership after the Mexican Revolution, in the 1910s and 1920s, the government of Lazaro Cardenas distributed land to small farmers and offered significant state support for agriculture. This policy was curtailed by the neo-liberal deregulation reforms of the Salinas and Zedillo governments, which included the NAFTA agreement with United States and Canada. These changes radically altered the living conditions of coffee producers, squeezed on one side by local buyers known as "coyotes," who bought coffee at the lowest price, and at the international level by price variations triggered by international stock markets and large multinationals. This situation had tragic repercussions in Mexico, the world's fifth largest coffee producing nation. Coffee ranks as the country's second most important export product after oil and ensures a living or survival for millions of Mexicans. The state of Oaxaca, one of the most politicized and diverse in terms of native populations, was determined to regain autonomy in this key crop production.

This is the context van der Hoff encountered when he arrived in the south of the state in 1980 . He worked for two years in plantations as a day labourer and in 1982 proposed not a solution but a collective problem analysis process based on the dialogue practice of Paulo Friere. After long dialogues, 150 representatives of three villages, including members of native tribes and Caucasians, identified two major problems: debt to the banks and the meagre sale price of their coffee. The analysis revealed that while the "coyotes" purchased the coffee at $\$ 0.25$ per kg, its real price including the farmers' labour was $\$ 0.65$. In addition, many bank officers pocketed the debt repayments. In 1983, UCIRI was founded as a cooperative with democratic management, an elected board of directors, representation of all partners, decision making by consensus, etc. By buying a truck, the cooperative could then sell coffee directly at the port of VeraCruz, without intermediaries, at $\$ 0.95 / \mathrm{kg}$. Systematic follow-up with the banks was also initiated. The reaction of the intermediaries was violent. For almost a decade, they sabotaged equipment and assassinated 37 villagers. The members of UCIRI nonetheless stood their ground, adopting the slogan of "together we will triumph". They reinvested a portion of their profits in essential infrastructures for their communities (roads, running water, electricity, telephone service, health services, schools, crops for local consumption, such as beans and corn, etc.). They also invested in coffee production (stores, warehouses, roasters, computers, cooperative credit bank, organic farming training centre, etc.).

In 1986, UCIRI decided to produce only organic coffee that abides by five principles: protection of biodiversity, waste water management, erosion control, elimination of pesticides and chemical fertilizers, recycling, waste reduction and compost use. In modern agriculture, everything revolves around expansion, growth and increased earnings. By cutting down all the trees and all the bushes, it is possible to plant 10,000 coffee plants on one hectare. Production per hectare is then optimal, but after seven or eight years the soil becomes sterile. On the other hand, organic agriculture tries not to increase but to improve. The small farmers in UCIRI planted 1000-2,000 coffee plants per hectare. UCIRI coffee has not only improved the social situation of the farmers, it has also improved the ecological situation of the region (Roozen and van der Hoff, 2001, p. 47).

All these innovations were particularly well received by the communities because they were consistent with ancestral values of autonomy, democracy and respect for nature. At UCIRI, the values of democracy and ecology emerged from the ancestral values of the native populations and were established communally. In addition, this cooperative considers exporting not as part of strategy of growth and market domination, but as an activity to pursue after the basic needs that have to be met to improve local living conditions. For UCIRI's small farmers, the economic argument is not primordial. The important thing is to leave their children and grandchildren an intact, beautiful Earth. They reject the ethos of perpetual growth and market domination. In their view, growth is less important than 
improvement. In the culture of the indigenous producer, there is an original, prior situation to the one they experience, that of a fair world, which allows satisfaction of primordial needs: working the soil to feed themselves and their family, clothe themselves and maintain good health. The right to the earth is as important as the right to eat. They talk about the earth with much respect, as Mother Earth that generates life thanks to work, sowing, rain and care provided (van der Hoff, 2005, p. 110). Frans van der Hoff posits that the values and cosmology of small farmers and native populations run counter to those of city dwellers and deserve greater recognition. Specifically, he asserts the need to evaluate the social and ecological costs of the "replacement" of small farms by agro-industries which could soon dictate what one must eat and how to digest it (van der Hoff, 2005, p. 86).

With the help from the contacts of Frans van der Hoff, UCIRI became the first exporter of FT coffee to Europe, under the Max Havelaar label, thus gaining autonomy which has allowed them to weather market fluctuations and oligopolies. Today, UCIRI spans 53 villages and 2,300 families. The profits earned by these small producers have skyrocketed by $300 \%$, and they are branching out into new products, such as jam and clothing.

Boosted by the success of UCIRI, FT proponents around the world gradually established both economic and extra-economic FT principles, including the following (Murray and Raynolds, 2000; Roozen and van der Hoff, 2001, pp. 244-248):

- Carry out direct trade, that is, limit the number of intermediaries between the producer and the consumer, the two stakeholders considered central to FT.

- Offer fair wages to producers or an integral price, slightly higher than the market price, which covers not only the economic costs related to production of a good or service but also the social and environmental costs.

- Promote long-term commitment and sustainable and transparent relations between economic partners, and not focus exclusively on shortterm profits as the ethos of perpetual growth dictates.

- Supply technical and financial support to producers in the South. This support can take the form of pre-financing that allows producers to live comfortably between crops, guarantees a minimum purchase price despite stock market fluctuations, and provides technical aid to improve work and management methods. Some of these principles are similar to the ones adopted by the co-operative movement founded by the Rochdale society.

- Favour democratic management of producing organizations, most often based on the co-operative model. Work co-operatives offer several advantages, including member participation in decision making and reinvestment of surpluses in community projects. They also facilitate the learning of democracy, the repercussions of which go beyond the framework of the organization.

- Support sustainable development, i.e. preserve biodiversity and renewable natural resources by promoting poly-culture, avoiding pesticides and chemical fertilizers, and decreasing pollution and waste.

- Promote consumer education on responsible consumption. All FT partners are encouraged to carry out educational activities to raise awareness among consumers, the general public, companies and political decision makers.

The first FT certification in the world was the Max Havelaar label, named after a famous book published in the Netherlands. Under the alias Multatuli ("I have suffered a lot" in Javanese), Dutch writer Eduard Douwes Dekker (1820-1887) introduced the protagonist Max Havelaar in 1860 in a novel that denounced the Dutch colonial system in Indonesia (Multatuli, 1987). Like the English in India or the French in Indochina, the Dutch exploited the natural wealth of Indonesia for several centuries to the detriment of local populations. In the novel, the hero Max Havelaar speaks out against the oppression of the Javanese coffee growers and the tactics of Dutch exporters who sought to keep the purchase price as low as possible. When Frans van der Hoff met Nico Roozen in 1985, the situation described in the book still prevailed. Roozen was working for Solidaridad, an interfaith humanitarian development organization in Latin America, since 1984. Both no longer believed "in the large development projects 
put in place nor in the virtue of intermittent donations" (Roozen and van der Hoff, 2001, p. 10). Roozen and van der Hoff were convinced that between $7 \%$ and $15 \%$ of consumers would be willing to pay slightly more for their coffee if they knew that this surplus would be used to truly improve the living conditions of the producers. Two ideas were put forth: create a distinctive brand of coffee or promote a quality label. The second option was retained, spawning the Max Havelaar label. The first bag of FT coffee was sold in a large department store in the Netherlands on November 15, 1988. Before this date, "ethical" coffee was sold in specialty stores to enlightened consumers. However, the coffee growers were able to sell only a minute portion of their production to this specialized market. Since the label Max Havelaar was created, many FT products were no longer confined to specialty stores: they were sold in conventional stores, department stores, restaurants and hotels. The FT label legitimizes the product, not just the specialty store where the product is sold. Labels, such as Max Havelaar are administered by independent non-profit organizations. The penetration of traditional distribution circuits is the keystone of the strategy envisioned by van der Hoff and Roozen.

The FT certification was then extended to other producers and products, such as Oké bananas or Kuyichi Jeans. In addition, many other FT certification systems were created (Fairtrade, Transfair, etc.), grouped within Fair Trade Labelling Organizations International (FLO). These organizations neither purchase nor sell FT products; rather, they manage FT certification and labelling in different countries. The FLO applies rigorous guidelines that uphold the integrity of its certification-related decisions. It applies international FT standards, revised regularly in close cooperation with the main stakeholders, who are represented on its board of directors. The organization defines the certification standards by product type and verifies compliance with these standards among producers, importers, processors and distributors through administrative processes and physical inspections. It also coordinates technical, financial and organizational support for producers. The FLO is a member of FINE, a forum that brings together four international movements that promote FT, and of ISEAL, an international network of organizations that manages social and environmental certification, accreditation and labelling systems (Nicholls and Opal, 2005; van der Hoff, 2005).

\section{What could the Fair Trade movement bring to traditional business ethics?}

We have identified five characteristics of the FT movement that are particularly interesting for enriching the current practices of business ethics. None of these characteristics is unique to FT, but FT is a compelling example of the possibility to combine them in a single model of business ethics in international trade relations.

First, FT shows that rather than through international donations or charity, relations between countries in the South and the North can rest on openness of markets to small producers, under nonexploitative conditions. It is estimated that 48 of the poorest countries on the planet carry out only $0.4 \%$ of global trade; their market shares have shrunk by $50 \%$ since 1980. In addition, 500 multinationals currently control two-thirds of this trade and the five largest multinationals generate about the same amount of revenue as the 48 poorest countries (Curtis, 2001). To restore a balance, the rich countries grant international aid. But today this aid represents $<0.05 \%$ of the GDP of the donor countries, totalling roughly US $\$ 80$ billion compared with US $\$ 1,000$ billion in current military spending. Further, it is estimated that $80 \%$ of this aid, even when administered by international organizations or NGOs, often never reaches its destination for various reasons: contractual clauses requiring the purchase of Western products and services; fraud and corruption in the donating countries, receiving countries and organizations; expatriates' salaries at Western levels; use of new Volvo trucks or Toyota 4X4s; etc. (van der Hoff, 2005, p. 176). Moreover, allocation of the aid is often an opportunity for donor countries to exert political pressure on the receivers (United Nations, 2005).

When he became conscious of some of the wrongdoings of international aid, van der Hoff declared, in a deliberately exaggerated statement, that "giving charity is a mortal sin" (van der Hoff, 2005, p. 171). The workers and farmers who he helped shared their views. The true initiators of the Max Havelaar project were the poor Indians who 
told him "We do not want your donations. We are not beggars. Real support would be to pay us a fair price for our coffee" (Roozen and van der Hoff, 2001, p. 34). For van der Hoff, these words express, till today, the crux of the problem, from both the theological and economic standpoints. For him, charity treats the poor as objects, not as people, blurring the difference between means and ends, a notion introduced by Emmanuel Kant (Bowie, 1999). From this point of view, FT is seen as a viable alternative to international aid and charity because it strives to achieve a better balance of wealth in our so-called "globalized" world. In a similar vein, during the first United Nations Conference on Trade and Development (UNCTD) in 1964, representatives of Third World countries affirmed that their country's socio-economic development would be better served by commercial trade than by humanitarian aid. This opinion was encapsulated in the expression "Trade, not Aid" popularized in the 1970s by, for example, Roddick (2000), then CEO of the multinational The Body Shop, and by Nobel Prize laureates in economics (Sen, 1991; Stiglitz and Charlton, 2006).

Second, the success of FT shows that the price of a product needs not to be determined solely by the law of supply and demand but also by the calculation of a cost price that ensures dignified living conditions for the producers, even those who are powerless, including healthy social and ecological conditions. FT proponents disagree with the neo-liberal thesis of Milton Friedman or Friedrich von Hayek, which stipulates that the price of a good has no possible objective basis apart from the balance between its supply and demand on the market (von Hayek, 1960, p. 87). The concept of integral price is central to FT. Proponents argue that the objective price of a product comprises several costs. The real production cost leads to production of a quality product; the social cost allows producers to live in dignity from their labour and develop essential infrastructures; the environmental cost ensures that production respects the natural environment, whereas reasonable costs of transportation and distribution can be attained by eliminating middlemen as much as possible (Roozen and van der Hoff, 2001, pp. 244-248).

At a time when many companies are outsourcing their production to Third World countries and sometimes pay miserable salaries, which they justify by claiming that they are creating jobs in these countries, FT offers a powerful alternative to abuses. For example, the multinational Nike has been criticized for hiring children between the ages of 5 and 10 who worked $70 \mathrm{~h}$ per week in Indonesia earning $\$ 0.60$ per day (Bakan, 2004; Boggans, 2001). Generally, FT products are slightly more expensive than products sold in conventional trade: often the reduction, in FT, of the profit margin realized by the large companies does not compensate for the additional integral costs. Furthermore, because of the small scale of the operations and organic farming, FT cannot benefit from large economies of scale and certification may also be costly (Melo and Wolf, 2005; Moore, 2004, p. 79). This difference in price can be defended if the truly superior quality of FT products is acknowledged. The general public must also be made aware through educational efforts that social and ecological costs are not "externalities," as classic economic theory specifies, but instead are integral costs that must be included in the sale price (Stiglitz and Charlton, 2006).

Third, the FT movement suggests that a company's ethics can be evaluated by an accreditation system that independently rates both the local production conditions and the management practices in use. The mechanisms of certification and control are intended to guarantee that the weak links of the chain, such as small producers, receive an equitable portion of the profits. Certification is the cornerstone of FT, legitimizing it from consumers' standpoint. The first certified product was coffee harvested by the Mexican cooperative UCIRI that van der Hoff helped to create. Currently, countries, such as France are contemplating to put in place a new national certification for FT products. The Palais de l'Élysée has adopted FT coffee while the Netherlands wants $10 \%$ of its products to be "organic" and Germany is aiming for 20\% (Roozen and van der Hoff, 2001, p. 273). Because certification is one of the essential characteristics of FT, its implementation at the international level is fraught with significant political, cultural and logistical problems. Other forms of certification controlled by multiple organizations, such as certification for organic products or locally grown products, are hampered by similar constraints. Time will tell whether the FLO will successfully negotiate all these partnerships and avoid excessive bureaucratization. 
Given its success in several markets, FT has also attracted formidable adversaries. The introduction of Oké bananas, for example, a FT product, has triggered defensive strategies by multinationals, such as Dole, Del Monte and Chiquita. With annual sales in excess of US $\$ 10$ billion, these multinationals launched their attack on the FT movement by asserting that it cannot sustain quantity or quality due to its decentralized productive, logistical and delivery systems. In addition, realizing that nearly a quarter of consumers consider themselves "ethical", and that one in five consumers has rewarded or penalized a company through their purchases (Bird and Hughes, 1997, p. 160; Goodpaster et al., 2006, p. 597), these multinationals began to "polish" their reputations. For instance, they adopted different codes of ethics, mission statements, charters of values, commitments to social responsibility and sustainable development and created sophisticated Internet sites. They have also amassed certifications awarded by rating agencies whose criteria may be considered by many as far from stringent. For example, some certifications do not require independent controls but only selfassessments. Furthermore, in the coffee industry, the multinational Nestle has introduced the brand Partner Blend, which only requires a small percentage of the production process to be carried out within some organic guidelines. Given this proliferation of declarations, ratings, certifications and labels, many analysts believe that one of the main challenges to the survival of FT is the recognition of its distinctive label (Bird and Hughes, 1997; Davies and Crane, 2003; Melo and Wolf, 2005; Moore, 2004; Renard, 2003).

Fourth, FT shows that an alternative international trade can be developed through an alliance between small producers and consumers better aware of responsible consumption. From the very beginning and till today, the small farmers of UCIRI were community-oriented human beings for whom the important thing was to maintain harmony in the world and with the world. Relations with others were governed by the principle of reciprocity, and exchanges considered as normal conditions of existence of the community. In these exchanges, it is not the economic or symbolic value that takes precedence but rather the act itself (van der Hoff, 2005, p. 110). To say it another way, the UCIRI people do not see themselves as poor farmers demanding a special price protection measure, but rather as producers proud of their production sold to consumers who are more sensitive to a more humane and ecological approach. According to Nobel Prize winning economist Joseph Stiglitz, the greatest challenge to FT lies not in institutions but in people's minds (Stiglitz, 2002; Stiglitz and Charlton, 2006). In the same vein, other authors, such as Chatzikadis et al. (2007) consider that the FT movement is mostly dependent on psychology, in that it results from individuals making the choice to participate in the responsible consumption movement. For these authors, consumption, as the ultimate stage of the economic process, plays a vital role in determining ethical choices throughout the system (Davies and Crane, 2003; Mance, 2005; Nicholls and Opal, 2005). This consumption can either encourage oppression and injustice or differently trigger an emancipation process. In addition, responsible consumption is seen as an alternative to a traditional boycott. Whereas a boycott is an organized interruption of the purchase of one or more products intended to compel a company to modify its practices, responsible consumption lets consumers incorporate their choices in a purchase, in keeping with the idea of "buying is voting" (Mance, 2005; Waridel, 2005).

For van der Hoff (2005), the alliance between producers and consumers is at the heart of FT: both groups agree on the trade rules to avoid harming anyone. In his view, this trade is both a rebellion and a proposition: It is a different model, a market model in the market. For van den Hoff, free trade theory which, supposedly, ensures a balance between supply and demand, underestimates two essential factors: the social cost for the producers, who have no real power over the market and are, moreover, prevented from participating in it; and the wish of the consumers, who each day become more demanding in terms of quality and who request to better understand the origin and the process of merchandise through the production chain. To say it another way, FT proponents are trying to rescue small producers and consumers alike from economic anonymity. For van der Hoff, producers, distributors and consumers can jointly determine, through dialogue, the production conditions and the prices of products, which can in turn make the market more transparent and 'free'. Whereas FT is often perceived 
to be opposed to free trade, van der Hoff insists that it is in fact based on the concept of concerted and responsible freedom. By emerging from anonymity and engaging in dialogue, the producer and consumer can jointly make decisions and define the rules of the game, people gaining their freedom by taking on responsibilities. Hence, FT redefines the idea of 'free market' by giving it back its original meaning of freedom (Roozen and van der Hoff, 2001, p. 49).

Finally, FT asserts that a profound human source of ethics is to be discovered by living with people who are poor and without power thus allowing, through empathy, the development of responsibility between others and self. When he taught at the University of Ottawa, van der Hoff used to think that social and economic problems and injustice were caused by rabid imperialism perpetrated by ignorant people. To solve these problems of injustice, van der Hoff offered purely theoretical solutions based on class struggle, revolution, equality and democracy. He now admits that this view was misguided and could not really help the small producers. He further confesses that it is the poor people themselves who educated him. But in order to be really educated, he had to restrain himself from listening to what they had to say with benevolent paternalism. He had to go beyond mere awareness through empathy, i.e. a deep experience of relating to others (van der Hoff, 2005, p. 151).

For van der Hoff, only suffering can teach empathy. It is suffering that allows accountability towards others. As he stated: "I am convinced that the most human morals are found today in suffering in its broadest sense: individual, social, cultural and religious. Wanting to escape this experience is tantamount to trying to escape all morality" (van der Hoff, 2005, p. 151). He further emphasized that suffering is the daily lot for millions of people, who, far from letting themselves be overwhelmed, face it courageously and with dignity (van der Hoff, 2005, p. 151). In such a view, Van der Hoff differentiates between misery that atrophies the human spirit and poverty, which can be endured with dignity. For him, standing by the poor means sitting near a source of grace and poor people are the historical messengers of salvation and happiness. As he stated: "Thanks to them we can follow the course of history, we can understand the meaning of our existence. It is the poor, the indigent, the small farmer that offers hope for a bright future. It is they that give time its depth, that let us question the exploitative economic system, the political system that excludes and the social system that denigrates" (van der Hoff, 2005, p. 153). It would be easy to attribute these views to the fact that van der Hoff is a worker-priest. Yet Adam Smith, the father of the market economy, reached the same conclusion. In a sentence often forgotten, Smith declared that the "disposition to admire, and almost to worship, the rich and the powerful, and to despise, or at least, to neglect persons of poor and mean condition, [is] the greatest and most universal cause of the corruption of our moral sentiments" (Smith, 1976, p. 61).

In a similar vein, Tom Peters and Robert Waterman popularized the concept of "management by walking around", urging CEOs and senior managers to descend from their ivory tower (Peters and Waterman, 1982). But it seems that Frans van der Hoff went even further, advocating the need of "management by living with", rooted in the experience of living alongside people without power, with firsthand knowledge of suffering and despair. It is important to note that in the example of child exploitation by Nike mentioned above, CEO Phil Knight, who publicly apologized for these practices, admitted that he had never visited this country, never experienced "living with" the people who manufacture his company's products (Moore, 2002). In stark contrast, even when she was the extremely busy CEO of multinational The Body Shop, Roddick spent several weeks a year with the farmers who supplied the company, sharing their daily way of life (Roddick, 2000). For similar reasons, each year many companies send some of their staff, from employees and managers to members of the boards of directors, to developing countries so that they can meet the population and social stakeholders, such as teachers, mayors and entrepreneurs (Roddick, 2000). To take another example, in the innovative MBA program designed by Henry Mintzberg of McGill University, each student is asked to spend at least one month in India, Mintzberg affirming that this experience is the one which is the most remembered (Mintzberg, 2004). These approaches are a far cry from traditional education and practices in business ethics, such as the drafting of a code of ethics or developing a public relations campaign. 


\section{Concluding remarks}

The FT has now become an international movement, representing the common will of many individuals and organizations. In Southern countries, it improves the living conditions of over 5 million people, including farmers and their families (Nicholls and Opal, 2005; van der Hoff, 2005). Sales of FT have been evaluated in 2002 at US $\$ 500$ million per year and its expansion varies considerably by product and country (Moore, 2004, p. 74). For example, FT coffee in France today represents 2\% of the market and is growing rapidly. FT coffee has been integrated into large French distribution chains, such as Auchan and Carrefour, as well as hotel and restaurant chains, such as Accord. In Switzerland, a country not protected by European Union quotas, FT coffee represents $8 \%$ of the market and FT bananas $47 \%$. By comparison, FT coffee accounts for $20 \%$ of Mexico's exports (Krier, 2005; Moore, 2004; Roozen and van der Hoff, 2001, p. 134, 266; van der Hoff, 2005, p. 171).

The FT movement faces several profound challenges, including the risk of becoming a victim of its own success (Hira and Ferrie, 2006). It faces the following dilemma: if its presence on the market is too small, it cannot meet the needs of many small producers nor affect conventional trade, while excessive prominence may be co-opted by the large traditional economic players. For example, Wal-Mart, the largest distributor in the world, has announced that it also wishes to become the greenest by distributing the largest quantity of "ecological" products. Today, Wal-Mart is already the largest seller of organic milk in the world and the largest buyer of organic cotton (Gunther, 2006, p. 36). FT has also been criticized repeatedly by proponents and detractors alike (Audebrand and Iacobus, 2008). Notably, FT is decried for being only another form of charity that is not fundamentally different from humanitarian aid, because it appeals to the social awareness of consumers. FT has been further criticized for its higher cost to consumers and for offering, in a sense, products accessible only to the rich members of society. Other observers consider that reducing the proportion of subsistence agriculture in favour of export crops perpetuates dependence within Third World countries (Strong, 1997).
Nonetheless, we have argued in this article that the FT movement, triggered by van der Hoff, the UCIRI cooperative and the Max Havelaar organization, has much to offer to current Western-centric business ethics through five characteristics:

1. Rather than through international donations or charity, relations between countries in the South and the North could rest on openness of markets to small producers, under nonexploitative conditions.

2. The price of a product needs not to be determined solely by the law of supply and demand but also by the calculation of an integral price. This different calculation can ensure more dignified living conditions for the producers, even those who are powerless, including healthy social and ecological conditions.

3. A company's ethics can be judged by an accreditation system that independently evaluates local production conditions and management practices.

4. A distinctive international trade can be fostered through an alliance between small and disenfranchised producers and consumers, more aware of responsible consumption.

5. Finally, a profound human source of ethics is to be uncovered by living with people living in poor conditions, without power, thus allowing, through empathy, the development of a sense of responsibility between others and self.

Not emerging from the rich West and integrating different social movements and diverse spiritual heritages, the FT movement challenges the way that corporations do business as well as the current economic ideology. In addition, the FT movement has not emerged out of theoretical grounds but instead from the experiences and involvement of disadvantaged populations, much like the micro-credit movement initiated by the Nobel Prize winner Muhammad Yunus (2001). The FT movement has become a concrete trend that involves several millions of people, as well as several hundred millions of dollars of transactions. Only the future will tell us if this movement will preserve the spirit of its founders and make a significant contribution to contemporary business ethics. 


\section{References}

Almanza-Alcade, H.: 2002, Transnational Social Movements, Solidarity Values and the Grassroots: The Fair Trade Movement, Mexican Coffee Producers and a European NGO Coalition. Unpublished Dissertation, University of Sussex at Brighton.

Audebrand, L. K. and A. Iacobus: 2008, 'Avoiding Potential Traps in Fair Trade Marketing: A Social Representation Perspective', Journal of Strategic Marketing 16(1), 3-19. doi:10.1080/09652540701794379.

Bakan, J.: 2004, The Corporation. The Pathological Pursuit of Profit and Power (The Free Press, New York).

Bird, K. and D. G. Hughes: 1997, 'Ethical Consumerism: The Case of "Fairly-Traded" Coffee', Business Ethics: European Review (Chichester, England) 6(3), 159-167.

Boggan, S: 2001, 'Nike Admits to Mistakes Over Child Labor', The Independent, October 20.

Chatzikadis, A., S. Hibbert and A. P. Smith: 2007, 'Why People Don't Take Their Concerns About Fair Trade to the Supermarket: The Role of Neutralisation', Journal of Business Ethics 74, 89-100. doi:10.1007/ s10551-006-9222-2.

Ciulla, J., C. Martin and R. C. Solomon: 2007, Honest Work. A Business Reader (Oxford University Press, New York).

Curtis, M.: 2001, Trade for Life: Making Trade Work for Poor People (Christian Aid, London).

Davies, I. and A. Crane: 2003, 'Ethical Decision Making in Fair Trade Companies', Journal of Business Ethics 45, 79-92. doi:10.1023/A:1024124629399.

Frederick, W. C.: 2000, 'Notes for a Third Millennial Manifesto: Renewal and Redefinition in Business Ethics', Business Ethics Quarterly 10(1), 159-167. doi:10.2307/3857702.

Fretell, A. C. and H. O. Roca: 2005, 'Commerce équitable', in J.-L. Laville and A. D. Cattani (eds.), Dictionnaire de l'autre économie (Desclée de Brouwer, Paris), pp. 95-110.

Friere, P.: 2000, Pedagogy of the Oppressed, 30th Anniversary Edition (Continuum International Publishing, New York).

Goodpaster, K. E., L. L. Nash and H.-C. de Bettignies: 2006, Business Ethics. Policies and Person, 4th Edition (McGraw-Hill Irwin, Boston, MA).

Gunther, M.: 2006, 'Wal-Mart Saves the Planet: The Green Machine', Fortune, August 7, Cover Story, pp. 34-42.

Hira, A. and J. Ferrie: 2006, 'Fair Trade: Three Keys Challenges for Reaching the Mainstream', Journal of Business Ethics 63, 107-118. doi:10.1007/s10551-0053041-8.
ILO: 2004, World Employment Report 2004-2005 (International Labor Organization, Geneva).

Krier, J.-M.: 2005, Fair Trade in Europe 2005: Facts and Figures on Fair Trade in 25 European Countries (FINE, Brussels).

Mace, B.: 1998, Alternative Trade and Small-Scale Coffee Production in Oaxaca. Unpublished Master's Thesis. Miami University, Oxford, Ohio.

Mance, E. A.: 2005, 'Consommation Solidaire', in J.-L. Laville and A. D. Cattani (eds.), Dictionnaire de l'autre économie (Desclée de Brouwer, Paris), pp. 111-116.

McDonald, G. and P. C. Pak: 1996, 'It's All Fair in Love, War and Business: Cognitive Philosophies in Ethical Decisions', Journal of Business Ethics 15(9), 973-993. doi:10.1007/BF00705577.

Melo, C. J. and S. A. Wolf: 2005, 'Empirical Assessment of Eco-Certification. The Case of Ecuadorian Bananas', Organization \& Environment 18(13), 287-317. doi:10.1177/1086026605279461.

Mintzberg, H.: 2004, Managers Not MBAs. A Hard Look at the Soft Practice of Managing and Management Development (Berrett-Koelher Publishers, San Francisco, CA).

Moore, M.: 2002, The Big One (Miramax Films, New York).

Moore, G.: 2004, 'The Fair Trade Movement: Parameters, Issues and Future Research', Journal of Business Ethics 53(1-2), 73-86. doi:10.1023/B:BUSI.0000039 400.57827.c3.

Multatuli: 1987, Max Havelaar or the Coffee Auctions of a Dutch Trading Company (R. Edwards). (Penguin Books, New York, Orig. 1860).

Murray, D. and L. Raynolds: 2000, 'Alternative Trade in Bananas: Obstacles and Opportunities for Progressive Social Change in the Global Economy', Agriculture and Human Values 17, 65-74. doi:10.1023/A:10076287 09393.

Nicholls, A. and C. Opal: 2005, Fair Trade Market-Driven Ethical Consumption (Sage Publications, Thousand Oaks, CA).

Norget, K.: 1997, 'The Politics of Liberation: The Popular Church, Indigenous Theology and Grassroots Mobilization in Oaxaca, Mexico', Latin American Perspectives 24(5), 124-144. doi:10.1177/0094582X9702400506.

OECD: 2005, OECD in Figures, 2005th Edition (OECD Observer, Paris).

O'Fallon, M. J. and K. D. Butterfield: 2005, 'A Review of the Empirical Ethical Decision-Making Literature: 1996-2003', Journal of Business Ethics 59(4), 375-413. doi:10.1007/s10551-005-2929-7. 
Otero, G.: 1999, 'Neoliberal Reform in Rural Mexico: Social Structural and Political Dimension', Latin American Research Review 35(1), 187-207.

Pauchant, T. C.: 2002, Ethics and Spirituality at Work Breakthroughs and Pitfalls of the Search for Meaning at Work (Quorum Book, New York).

Peters, T. J. and R. H. Waterman: 1982, In Search of Excellence (Harper and Row, New York).

Renard, M.-C.: 2003, 'Fair Trade: Quality, Market and Conventions', Journal of Rural Studies 19, 87-96. doi:10.1016/S0743-0167(02)00051-7.

Roddick, A.: 2000, Business as Unusual (Thorsons, London, UK).

Roozen, N. and F. van der Hoff: 2001, L'aventure du commerce équitable (JC Lattès, Paris).

Samuelson, J.: 2006, 'The New Rigor: Beyond the Right Answer', Academy of Management Learning \& Education 5(3), 356-365.

Schein, E. H.: 1985, Organizational Culture and Leadership (Jossey-Bass, San Francisco, CA).

Schwartz, M. S.: 2005, 'Using Moral Values for Corporate Codes of Ethics', Journal of Business Ethics 59(1), 27-44. doi:10.1007/s10551-005-3403-2.

Sen, A.: 1991, Ethics and Economics (Blackwell Publishers, New York).

Shanahan, T. and R. Wang: 2003, Reason and Insight. Western and Eastern Perspectives on the Pursuit of Moral Wisdom, 2nd Edition (Thomson Wadsworth, New York).

Smith, A.: 1976, 'The Theory of Moral Sentiments', in D. D. Raphael and A. L. Macfie (eds.), (Oxford University Press, Orig. 1759-1790).

Stiglitz, J. E.: 2002, Globalization and Its Discontents (W. W. Norton and Company, New York).
Stiglitz, J. E. and A. Charlton: 2006, Fair Trade for All How Trade Can Promote Development (Oxford University Press, New York).

Strong, C.: 1997, 'The Problems of Translating Fair Trade Principles into Consumer Purchase Behaviour', Marketing Intelligence \& Planning 15, 32-37. doi:10.1108/ 02634509710155642.

Taylor, C.: 1989, Sources of Self. The Making of Modern Identity (Harvard University Press, Cambridge, MA).

United Nations: 2005, General Assembly, 10364 (June), 7 (U.N. Publications, New York, Press release).

van der Hoff, F.: 2005, Nous ferons un monde équitable (Flammarion, Paris).

von Hayek, L.: 1960, The Constitution of Liberty (University of Chicago Press, Chicago, Ill).

Waridel, L.: 2005, Coffee with Pleasure: Just Java and World Trade, 2nd Edition (Black Rose Books, Montréal).

Yunus, M.: 2001, Banker to the Poor. The Autobiography of Muhammad Yunus Founder of the Grameen Bank (The University Press Limited, Dhaka, Bangladesh).

Luc K. Audebrand

University of British Columbia (Okanagan Campus),

Kelowna, BC, Canada

E-mail: luc.audebrand@ubc.ca

Thierry C. Pauchant

HEC Montréal,

Montréal, QC, Canada

E-mail: thierry.pauchant@hec.ca 